\title{
Muscle Spindle and Comparison of Fish Muscle Spindle with Other Vertebrates
}

\begin{tabular}{l|c}
\hline Review / Derleme & Souad Salah ADEM ${ }^{1,2}$, Mahmut ELP ${ }^{3} *$ \\
Received / Geliş Tarihi & \\
27.09 .2017 & ${ }^{1}$ Department of Aquaculture, Institute of Science, \\
Accepted / Kabul Tarih & Kastamonu-Turkey \\
11.12.2017 & ${ }^{2}$ Benghazi University, Science Faculty, Taucheira Campus, Taucheira- \\
DOI & Libya \\
10.28955/alinterizbd.340209 & ${ }^{3}$ Kastamonu University, Fisheries Faculty, Kastamonu-Turkey \\
ISSN 2564-7814 & $*$ e-posta: mahmutelp@ kastamonu.edu.tr \\
e-ISSN 2587-2249 & \\
\hline
\end{tabular}

\begin{abstract}
The aim of this study is to bring together the literature knowledge on muscule spindels that has been made up to until now and compare fish muscule spindels with other vertebrates. Muscle spindles are stretch receptor of skeletal muscles which detect the rate and degree of muscle length. According to the available literature, this review is considered as a one in making a comparison of fish muscle spindle and other vertebrates. Fish muscle spindle possesses single intrafusal muscle fiber similar to snake and lizard muscle spindle and have a double capsule similar in all vertebrates have studied. No significant differences in the length and diameter of intrafusal muscle fibers by comparison of muscle size. In fish and other vertebrates muscle spindles are supplied with one sensory ending (exception in mammalian may, in addition, be supplied with one or more secondary sensory endings) and receive its motor innervation from branches of axons that also innervate extrafusal muscle fibers. No investigation has been done about motor innervation of fish muscle spindle.
\end{abstract}

Keywords: Muscle spindels, fish anatomy, fish muscle

\section{Kas İğleri ve Balık Kas İğlerinin Diğer Omurgalılar İle Karşılaștırması}

Öz: Bu çalışmanın amacı bugüne kadar kas iğleri üzerine yapılan çalışmaları bir araya getirmek ve balıklar ile diğer omurgalıların kas iğlerini karşılaştırmaktır. Kas iğleri kas uzunluğunun oran ve yoğunluğunu belirleyen iskelet kaslarının germe reseptörleridir. $\mathrm{Bu}$ çalışma mevcut literatürlere göre diğer omurgalılar ile balık kas iğlerinin bir karşılaştırması olarak düşünülmüştür. Balık kas iğ yapısı tek intrafüzal kas lifi yılan ve kertenkelelere benzer ve bugüne kadar çalışılmış diğer omurgalılarda olduğu gibi çift kapsüllüdür. Kas büyüklüğü karşılaştırıldığında intrafüzal kas fibrillerinin uzunluk ve çapında önemli farklılıklar yoktur. Balık ve diğer omurgalılarda kas iğleri bir algılayıcı ile sonlanır (memeliler hariç, bir veya birkaç algılayıcı ile de sonlanabilir) ve ekstrafüzal kas liflerini sinir sistemine de bağlayan aksonların kollarından motor sinir bağlantısını sağlar. Balık kas iğlerinin motor sinir bağlantıları hakkında herhangi bir çalışma bulunmamaktadır.

Anahtar Kelimeler: Kas iği, balık anatomisi, balık kası

\section{INTRODUCTION}

Muscle spindles are complex neuromuscular end- organ in skeletal muscles of vertebrates sensitive to muscle length and changes in muscle length. They were first noticed and described in frog muscle by Weisman (1861). The essential feature of the muscle spindle its containment of nerve and muscle components. They are composed of small (intrafusal) muscle fibers that lie as bundles in parallel with ordinary (extrafusal) muscle fibers and receive both a sensory and a motor innervation. The middle region of spindle is called equatorial region and regions on both sides of the equatorial region is called polar regions (Sherrington, 1894). Although most of the previous studies indicate that the fish lacks the muscle spindle (Fesard and Sand, 1937; William et al., 1979), Maeda et al. (1983) have proposed appearance in the jaw closing muscle of fish, and has found monofibral spindles in this muscle in salmon. In fish the first observation was made by Maeda et al. (1983) where they observed it among the superficial extrafusal fibers of jaw- closing muscle, adductor mandibular in Oncorynchus masou (Brevoort, 1856). The receptor has not been confirmed; meanwhile Saed (1990) has made a comprehensive research for the receptor in the jaw-closing muscle of trout. There are no extensive 
studies on fish muscle spindle and little attention has been paid for it. The aim of the present study was to give a background on muscle spindle and compare fish muscle spindles with other vertebrates.

\section{Intrafusal Muscle Fibers}

Based on the study which carried out by Maeda et al. (1983) fish muscle spindle has single intrafusal muscle fiber and this homologous of snake (Palot and Ridge, 1972 ) and lizard (Proske, 1969) muscle spindle which possessed single intrafusal muscle fiber and this incompatible with Amphibian and Mammals muscle spindle which possessed more than one intrafusal muscle fiber inside their capsules named as bag bag $_{2}$ and chain fibers in Mammals (Banks et al., 1974) and as large and small intrafusal muscle fibers in Amphibians and bird spindles contained two or three types of intrafusal fiber but not categorized to nuclear bag and nuclear chain fibers and separable into types based on differences in myosin heavy chain composition and motor innervation (Mair, 1992).

\section{Length and Diameter}

The histological study performed by Maeda et al. (1983) on salmon muscle spindle revealed that the long of the intrafusal muscle fiber was $1.800 \mu \mathrm{m}$ and the diameter $2.8 \mu \mathrm{m}$ at polar region.

In frog large intrafusal fibers have mean diameters ranging between 9-37 $\mu \mathrm{m}$ depending on the muscle of origin, while small fibers have mean diameters 9-48 $\mu \mathrm{m}$ (Yoshimura et al., 1990).

In the avian muscle spindle the diameter of intrafusal muscle fiber in two synergistic skeletal muscles, the anterior (ALD) and posterior (PLD) latissimus dorsi varied from 5.0 to $16.0 \mu \mathrm{m}$ and 4.5 to 18.5 $\mu \mathrm{m}$, respectively (William K, 1999).

In mammals spindles, the bag fibers are the longest, the bag $_{2}$ generally being longer than the $\mathrm{bag}_{1}$. Kucera (1982) reported that mean polar lengths of $29.47 \mu \mathrm{m}$ for bag $\mathrm{b}_{2}$ fibers, $27.60 \mu \mathrm{m}$ for bag $\mathrm{b}_{1}$, and $12.31 \mu \mathrm{m}$ for typical chains (tenuissim of cat, frozen sections).

\section{Capsule}

Almost all vertebrates, including fish have the same capsule structure (Ovalle, 1976). Muscle spindle has an outer and an inner capsule. The capsule is lamellate structure that encloses the sensory innervation, its width range between 100 to $150 \mu \mathrm{m}$ at equator and the length usually between 2 to 4 $\mathrm{mm}$ and varies according to the number of sensory endings present. The capsule lamellae are consists of several concentric and tangent cell layers alternating with layers filled with collagenous fibrils. The outermost capsule layer is composed of thick collagenous fibrils and scattered fibrocytes. The innermost layer is composed of a lining of fibrocytes (Ovall and Dow, 1988)

\section{Number and Distribution}

Different muscles possess characteristic number of spindles, although there is considerable individual variability, at least in an outbred population (Chin et al., 1962). Quantitative comparisons have normally been made using spindle density, which is simply the number of capsules per gram of the adult muscle. On this basis it is often stated that spindles are relatively common in small muscles involved in fine control, such as the intrinsic muscles of the hand (Cooper, 1960). Several detailed maps are available showing the distribution of spindles and other encapsulated receptors in a variety of muscles. Some of the best, together with additional references, are given by Van der Wal (1988).

Two important features of the distribution of spindles emerge from the maps, as originally described by Gregor (1904) and Yellin (1969):

i) Spindles are concentrated in the region of nerve entry and around the subdivisions of the intramuscular nerves.

ii) They occur preferentially among extrafusal fibers with a high proportion of oxidative.

\section{Innervations}

The muscle spindle has both sensory and motor components.

\section{Sensory innervation}

According to the study conducted by Maeda and his colleagues on the salmon, there is primary nerve ending in which makes a large spiral course around the intrafusal fibre.

In mammals Primary and secondary sensory nerve fibers spiral around and terminate on the central portions of the intrafusal muscle fibers (equatorial regions) in innulospiral form, providing the sensory component of the structure via stretch-sensitive ion-channels of the axons and Spirals are common and more extensive around chain fibers than bag fibers (Hulliger, 1984) 
Secondary endings terminate on one or both sides of the primary, and most secondaries terminate next Allintert to the primary (Van der Wal, 1988).

\section{Motor innervation}

The study has conducted on the salmon muscle spinde hasn't refer to the motor innervation and at the same time there have been many studies on innervation of extrafusal fibers (Johnston and Moon, 1981) and also physiological studies about fish proprioception (Williams and Hale, 2015; Rivera et al., 2014) where they have mentioned that the sense of position and movement of the paired and/or unpaired fins is critical for executing rapid motor behavior in fishes. However, the location of the proprioceptive receptors involved in proprioception of fin movement is unknown.

In Mammals including humans, the motor component is provided by up to a dozen gamma motoneurons and to a lesser extent by one or two beta motoneurons (Vallbo and Falahe, 1990). Gamma and beta motoneurons are called fusimotor neurons, because they activate the intrafusal muscle fibers. Gamma motoneurons innervate only intrafusal muscle fibers, whereas beta motoneurons innervate both extrafusal and intrafusal muscle fibers and so are referred to as skeletofusimotor neurons (Taylor, 2005).

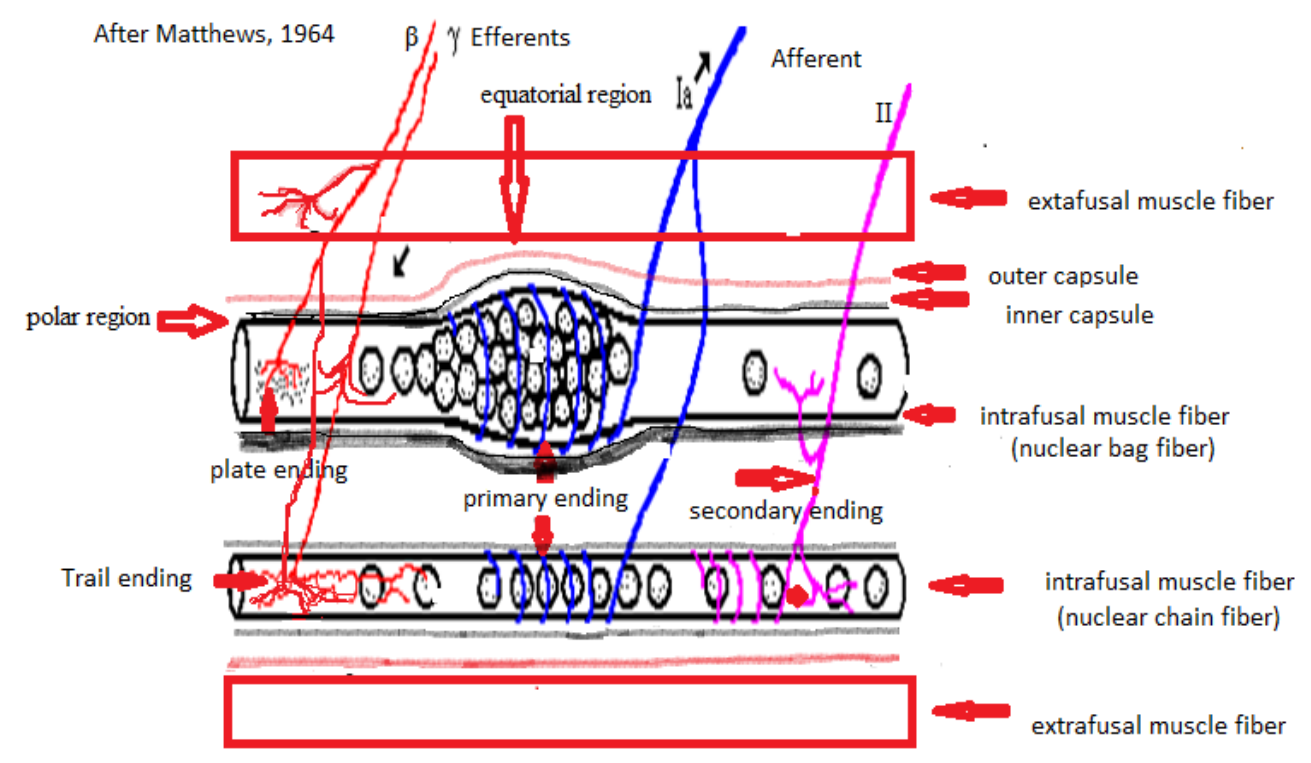

Figure 1. Diagram showing the principle components of typical muscle spindle, (modified from Matthews, 1964)

\section{CONCLUSION}

The majority of studies on muscle spindle morphology, distribution and function have been conducted on mammalian skeletal muscles (Matthews, 1962; Barker, 1974; Boyd and Smith, 1984). Comparatively little information exists on fish muscle spindles and the degree to which they resemble or differ from those of other vertebrates therefore these comparisons were made. So the aim of this review article was to summarize and compare recent and previous findings on fish muscle spindle and other vertebrates.

Maeda et al., (1983) showed that the muscle spindle has a single intrafusal muscle fiber and this is similar to snake and lizard muscle spindle (Proske, 1996) and compatible with capsule structure of most vertebrate by its content on inner and outer capsule (Ovalle, 1976). There are measurement differences in length and diameter of intrafusal muscle fiber and capsule among muscle spindles of vertebrates and those refer to the differences in size and location of the muscles (Barker, 1974). The number and distribution of muscle spindle varies through species and this finding agrees with the earlier reports by Zelena (1994) that each muscle contains a characteristic number of spindle which also species - specific and is apparently genetically encoded. 
The sensory innervation in salmon similar to most vertebrate classes in having one primary ending Altintert exception in some Mammals contain primary and secondary sensory end (Adal, 1984).

No investigation has been made on motor innervation in fishes. Therefore, comprehensive research should be carried out for muscle spindle in fish muscles in different species.

\section{REFERENCES}

Adal, M. N., 1984. The sensory and motor innervation of muscle spindles in cat tail dorsolateral muscles. J. Anat 138: 237-249

Banks, R. W., Harker, D. W., Stacy, M.J., 1974. A study of mammalian intrafusal muscle fibers using a combined histochemical and ultrastructural technique. J. Anat 123:783-796

Barker, D., 1974. The morphology of muscle receptors. In Muscle Receptors. Handbook of sensory physiology. (ed. C.C. Hunt), Springer verlag, Berlin, 1(2): 1-190

Boyd, I. A., Smith, R., 1984. The muscle spindle. In Peripheral Neuropathy. (ed. Dyck PJ, Thomas PK, Lambert EH, Bunge R), Philadelphia: W. B. Saunders, pp. 171-202

Chin, N. K., Cope, M., Pang, M., 1962. Number and distribution of spindle capsules in seven hindlimb muscles of the cat. In Barker D (ed) Symposium on muscle receptors. Hong Kong, Hong Kong university press, pp 241- 248

Cooper, S., 1960. Muscle spindle and other muscle receptors. In Bournce G H (ed.) The structure and Function of Muscle, New York, Academic Press

Fessard, A., Sand, A., 1937. Stretch receptors in the muscles of fishes. Laboratory of the marine biological Association, Plymouth 14(4):383-404

Gregor, A., 1904. Uber die Vertheilung der Muskelspindeln in der Musculatur des Menschlichen Fotus. Arch Anat Physiol. (Anat Abstr), 112-191

Hulliger, M., 1984. The mammalian muscle spindle and its central control. Rev. Physiol. Biochem. Pharmacol 101: $1-110$

Johnston, I. A., Moon, T. W., 1981. Fine structure and metabolism of multiply innervated fast muscle fibres in teleost fish .J. Cell Tissue Res 219(1):93-109

Kucera, J., 1982. Morphometric studies on tenuissimus muscle spindles in the cat. J Morphol 171(2): 137-150

Maeda, N., Myoshi S., Toh H., 1983. First observation of a muscle spindle in fish. Nature 302: 61-62

Maier, A., 1992. The avian muscle spindle. J. Anat and Embry 186: 1-25

Matthews, P. B. C., 1962. The differentiation of two types of fusimotor fiber by their effects on the dynamic response of muscle spindle primary endings. Q J EXP phisiol 47: 324-333

Ovall, W. R., Dow, P. R., 1988. The capsular sleeve of muscle spindles in mouse and man with special reverence to the cytoskeleton. In: Mechanoreceptor, Development, Structure and function, (eds P.Hink., T. Soukup., R. Vejsada. And J. Zelena).Plenum, New York. 255-261

Ovalle, W. K., 1976. Fine structure of the avian muscle spindle capsule. Cell Tissue Res 166(3):285-298

Page, S., 1966. Intrafusal muscle fibres in the frog. J. Microscopie 5: 101-104

Palot, D. J., Ridge R. M. P., 1972. The fine structure of the long capsule muscle spindles in the snake Natrix sp. J. Anat 113:61-74

Proske, U., 1969.The innervation of muscle spindle in the lizard Tiliqua nigrolutea. J. Anat 105:217-230

Rivera, M., Velez, S., Vazquez, T., 2014. Molinar R :Superficial neuromasts as proprioceptive receptors in poeciliid fish. J. FASEB 28:1050-11

Saed, H. H., 1990. A study of receptors in jaw muscles of the rat and other vertebrates. Ph.D. thesis, university of Durham, U.K.

Sherrington, C. S., 1894. On the anatomical constitution of nerves of skeletal muscles; with remarks on recurrent fibers in the ventral spinal nerve-root. J. Physiol 17: 211-258

Taylor, A., Durbaba, R., Ellaway, P. H., Rawlinson S., 2005. Static and dynamic gamma-motor output to ankle flexor muscles during locomotion in the decerebrate cat. J. Physiol. 571 (3): 711-723

Vallbo, A. B., Falahe, N. A., 1990. Human muscle spindle response in a motor learning task. J. Physiol. 421: 553-568

Van der Wal, J. C., 1988. The organization of the substrate of proprioception in the elbow region of the rat. Thesis, Rijksuniversiteit Limburg, Mastricht

Weisman, A., 1861. Über das Wachsen der Quergestreiften Muskein nach Beobachtungen am Frosch. Z. Rat Med 10:263-284

William, K., Ovalle, W., Pierre, R., Dow, E., Patrick, C., 1999. Structure, distribution and innervation of muscle spindles in avian fast and slow skeletal muscle. J. Anat 194: 381-394

Williams, R., Hale, M. E., 2015. Fin ray sensation participates in the generation of normal fin movement in the hovering behavior of the bluegill sunfish (Lepomis macrochirus). J. Exp Biol 218(21):3435-3447

Yellin, H., 1969. A histological study of Muscle Spindle and their relationship to extrafusal fibrer types in the rat. Am J. Anat 125(1): 31-45 
Alınteri Journal of Agricultural Sciences. 2017, 32(2): 113-117

Alınteri Zirai Bilimler Dergisi

Yoshimura, A., Fujitsuka, N., Sokabe, M., Naruse, K., Nomura, K., Diwant, H., Ito, F., 1990. Classification of the intrafusal muscle fibres in the frog muscle spindle: histochemical and immunofluorescent studies. J. Anat 172: 89-101

Zelena, J., 1994. Nerves and Mechnoreceptors. Chapman and Hall, Boundary Row, London, pp 71 